\title{
A Study on the Fabrication of an Effective Natural Substance Based on Schisandra chinensis Extracted Fermentation
}

\author{
Chi Thanh Nguyen (D) \\ Jong-Man $\mathrm{Han}^{2}$ \\ Van Huong $\operatorname{Tran}^{3}$ \\ Hun Jeong ${ }^{4}$ \\ Eun Sook Kim ${ }^{5}$
}

'Department of Materials Technology, Faculty of Applied Sciences, Ho Chi Minh City University of Technology and Education, Ho Chi Minh City, 700000, Viet Nam; ${ }^{2}$ Department of Physical Therapy, Daegu Health College, Daegu, 4|453, Republic of Korea; ${ }^{3}$ School of Mechanical Engineering, Hanoi University of Science and Technology, Ha Noi, 100000, Viet Nam; ${ }^{4}$ Department of Nano Convergence Engineering, Polymer Materials Fusion Research Center, Jeonbuk National University, Jeonju, Jeonbuk, 54896, Republic of Korea; ${ }^{5}$ Department of Beauty-Therapy \& Make Up, Seokyeong University, Seoul, 027।3, Republic of Korea
Correspondence: Hun Jeong;

Eun Sook Kim

Email feerself@jbnu.ac.kr;

poshop99@skuniv.ac.kr
Purpose: In this study, a high-efficiency Schisandra chinensis extract (SCE) produced by the fermentation of effective microorganisms (EM) was used as an antioxidant material in preparing cosmetic products.

Subjects and Methods: We conducted the study by extracting S. chinensis via EM fermentation to increase the efficiency. Tyrosinase inhibitory factor analysis, $\mathrm{pH}$, and thermal stability were measured to verify the properties of the prepared products.

Results: The efficacy and whitening effects of the prepared substances were verified using tyrosinase inhibitory factor analysis. As a result, it was found that both the SCE and SCE fermentation (SCEF) exhibited high, naturally originating, antioxidation ability. In addition, the $\mathrm{pH}$ and thermal stability of the substances were evaluated to optimize the cosmetic fabrication conditions. In this context, as the concentration of the added extract increased, the $\mathrm{pH}$ value decreased. The evaluation of safety and stability indicated that the substances contained effective chemical components having antioxidant activity, suppressing skin aging, and whitening effects in a weak acid range consistent with a $\mathrm{pH}$ of 6.25-2.98. Furthermore, there were no safety problems with the use of the obtained products even after they had been stored for 60 days.

Conclusion: The SCE substance is demonstrated as a possible material for cosmetic application.

Keywords: Schisandra chinensis, effective microorganisms fermentation, antioxidation

\section{Introduction}

In recent years, the improvement and the pursuit of high living standards have caused a lot of problems affecting people's health. Among these, cosmetic products are a particular example that needs to be carefully investigated. The use of synthetic chemicals as a main ingredient of cosmetic products leads to many negative results, spuuch as toxicity and high cost. This is the reason why the investigation of natural products for cosmetic applications has attracted a lot of interest from many researchers. Schisandra chinensis (SC) is a medicinal and edible plant that has five tastes (sweet, sour, bitter, salty, and pungent), ${ }^{1,2}$ and is widely used in many foods, drinks, and herbal industries, etc. ${ }^{3,4} \mathrm{SC}$ contains many bioactive compounds, such as gomisin, malic acid, and citric acid, and can be effectively used to treat cough and asthma. ${ }^{5}$ In addition, it can be used in the food and cosmetic industries owing to its well-known antibacterial and antioxidant abilities. Furthermore, it has excellent heat stability and can be used in cosmetics and 


\section{Graphical Abstract}

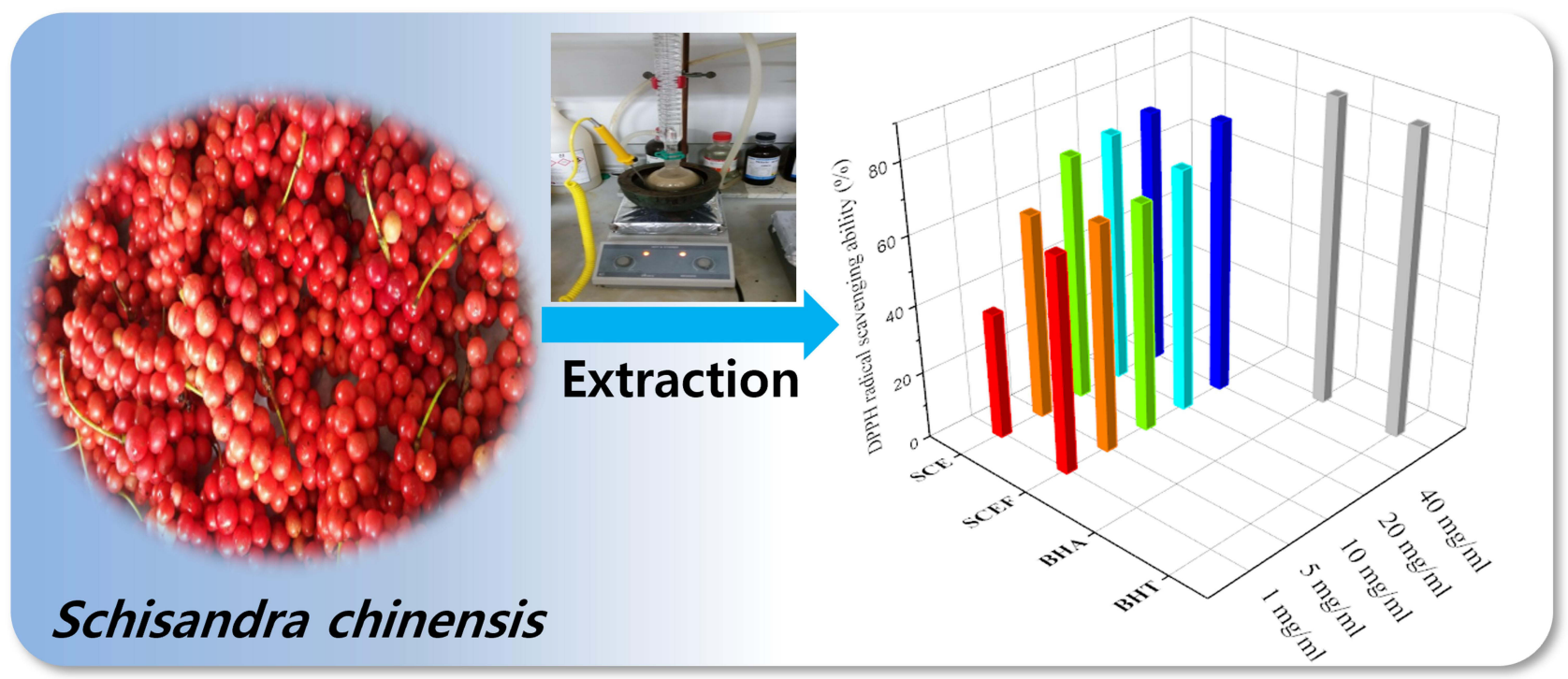

foods that do not affect people's health. ${ }^{6}$ Fermentation refers to the process of decomposing organic material using the enzymes of microorganisms, and is derived from the Latin word fervere. ${ }^{7}$ It has been used in various ways and in different fields, such as food, drugs, and cosmetics. $^{7}$ Food fermentation through the enzymatic action of microorganisms is traditionally used in manufacturing processes to improve flavor and destroytoxins, and also has the effect of promoting the biomolecules. ${ }^{8,9}$ Effective microorganisms (EM) are useful microorganisms which were developed in $1982 .{ }^{10}$ EM was originally developed for use in natural and organic farming. Subsequently, its applicable scope has been gradually extended and it is commonly used in Asian countries, Russia, and the USA. ${ }^{11}$ Initially, the solution of EM was developed from 80 species of 10 genera in 5 families; however, it was a very complex process. Therefore, EM was then simply developed by some principal organisms, such as photosynthetic bacteria, lactic acid bacteria, fungi, yeast, and actinomycetes. ${ }^{12}$ Regarding the fermentation application, it is fermented in facultative anaerobic conditions, so its synthesis products, such as vitaminand carotene pigments as powerful antioxidants to prevent the decay of organic material. ${ }^{13}$ The resulting amino acids and organic acids are converted to the respective proteins and sugars and then absorbed immediately by the plant. This improves greatly the efficiency of both the synthesis and use of plant food. EMwas originally developed for use in natural, organic agriculture, but nowadays is used in a variety of fields such as construction, medical, and cosmetic industries. ${ }^{14-16}$

In this study, SC was extracted by hot water and the extract broth was made by EM fermentation to increase the efficiency. Tyrosinase inhibitory factor analysis was used to determine the efficacy and whitening effects. Besides, the $\mathrm{pH}$ and thermal stability were measured to verify the stability of the prepared products, then the validity of the material with regard to the antioxidant and whitening effects of SC was evaluated.

\section{Materials and Methods \\ Materials}

SC fruits were purchased from a farm in the Republic of Korea. SC was treated with deionized (DI) water and then dried naturally in well-ventilated shade to produce the base material. Diethylene glycol (DEG, $\left(\mathrm{HOCH}_{2} \mathrm{CH}_{2}\right)_{2} \mathrm{O}$ ), folin-Ciocalteu's phenol reagent, sodium hydroxide $(\mathrm{NaOH})$, and sodium citrate tribasic dihydrate $\left(\mathrm{Na}_{3} \mathrm{C}_{6} \mathrm{H}_{5} \mathrm{O}_{7}\right)$ were purchased from Sigma Chemical Co. (USA). Purified DI water was used for all experiments. EM active solution, as a reagent for EM fermentation, was purchased from the EM Center, Jeonju University (Republic of Korea). 


\section{SC Extraction}

The dried SC was extracted using a reflux condenser 10 times in hot water after titrating. The extraction temperature was $80^{\circ} \mathrm{C}$, consistent with the extraction time of 24 h. Impurities were removed from the SC solution by a filtering process. The filtered solution was evaporated in a rotary evaporator $(\mathrm{N}-1000 \mathrm{SW})$, and then freeze-dried for one day to remove the solvent completely, leaving a solid product. The obtained product was stored in vacuum conditions during the experiments.

\section{Preparation of Different Extract Concentrations}

To compare and analyze the extract from ordinary SC and from EM-fermented SC, different concentrations of 1, 5, 10,20 , and $40 \mathrm{mg} \cdot \mathrm{mL}^{-1}$ were produced. In the case of the extract from EM-fermented SC, each portion of EMfermented liquor and sugar was maintained at $6 \%$ and $5 \%$. The extract from EM-fermented SC was incubated at $37^{\circ} \mathrm{C}$ for 7 days before being used.

\section{Microelement Analysis}

In accordance with the Food Code method, ${ }^{17} 1.0 \mathrm{~g}$ of the sample was dissolved in nitric acid $100 \mathrm{~mL}$ with DI water at $100^{\circ} \mathrm{C}$. Then, the amounts of trace elements in the sample were measured and analyzed with an Elemental Analyzer (Vario EL, Germany).

\section{Measurement of Polyphenol Content}

The polyphenol content per gram of the sample was measured by the Folin-Denis method. ${ }^{18}$ Thus, $100 \mu \mathrm{L}$ of extract and $2 \mathrm{wt} \% \mathrm{Na}_{2} \mathrm{CO}_{3}$ were mixed in an $\mathrm{EP}$ tube. The EP tube was kept at room temperature for 2 min for the reaction. After that, 50\% Folin-Ciocalteu's phenol reagent was added to the tube. The sample was put in a vortex mixer at room temperature for $30 \mathrm{~min}$, and then analyzed with a UV-Vis spectrophotometer at $750 \mathrm{~nm}$.

\section{Measurement of Flavonoids}

The total content of flavonoid per gram of extract was measured by diethylene glycol colorimetry. ${ }^{19}$ Thus, 100 $\mu \mathrm{L}$ of extract and $100 \mu \mathrm{L}$ of $1.0 \mathrm{~N} \mathrm{NaOH}$ were added to an EP tube and mixed using a vortex mixer. After mixing, the solution was kept at $30^{\circ} \mathrm{C}$ for $1.0 \mathrm{~h}$ for the reaction. The yield of the reaction was analyzed by a UV-Vis spectrophotometer at $420 \mathrm{~nm}$.

\section{Measurement of Free-Radical Scavenging}

The free-radical scavenging by 1,1-diphenyl-2-picrylhydrazyl (DPPH) was measured by the modified Blois method. ${ }^{20}$ In this context, $0.1 \mathrm{M}$ Trizma base- $\mathrm{HCl}$ buffer (Tris buffer, $\mathrm{pH}$ 7.4) and $500 \mathrm{mM}$ DPPH were initially prepared with methanol. Butylated hydroxytoluene (BHT) and butylated hydroxyanisole (BHA) were selected as standards for the control experiment. Then, $100 \mu \mathrm{L}$ of extract samples and $400 \mu \mathrm{L}$ of Tris buffer were mixed in an EP tube, followed by the addition of $500 \mu \mathrm{L}$ of DPPH solution. The mixture was kept in a dark room for $20 \mathrm{~min}$, then analyzed by a UV-Vis spectrophotometer at $517 \mathrm{~nm}$. In the control experiment, $100 \mu \mathrm{L}$ of BHT and BHA were added instead of the extract samples. In the non-additive group, $100 \mu \mathrm{L}$ of Tris buffer was added to the EP tube instead of the extract samples. The measurement of electron donation ability is shown as follows: ${ }^{21}$

$$
\begin{aligned}
& E D A(\%)=\left(100-\frac{\text { Absorbance of additive }}{\text { Absorbance of Non }- \text { additive }}\right) \\
& \times 100
\end{aligned}
$$

\section{Measurement of Nitrite Scavenging Activity}

The nitrite scavenging activity was measured using the modified method developed by Kim et al. ${ }^{22,23}$ Specifically, $0.3 \mathrm{~mL}$ of the extract sample and $0.1 \mathrm{~mL}$ of $1.0 \mathrm{mM}$ $\mathrm{NaNO}_{2}$ solution, $0.2 \mathrm{M}$ citrate buffer- $\mathrm{HCl}$ at $\mathrm{pH} 2.5$ was mixed to obtain a final volume of $1.0 \mathrm{~mL}$. The mixture was then reacted at $37^{\circ} \mathrm{C}$ for $1.0 \mathrm{~h}$. Subsequently, it was mixed with $0.4 \mathrm{~mL}$ Griess reagent $\left(30 \% \mathrm{CH}_{3} \mathrm{COOH}\right.$ solution containing sulfanilic acid (1.0 wt $\%)$ : naphthylamine $(1 \mathrm{wt} \%))$ and $3.0 \mathrm{~mL}$ of $\mathrm{CH}_{3} \mathrm{COOH}$ solution $(2.0 \mathrm{wt} \%)$. Then, the reaction took place at room temperature for $15 \mathrm{~min}$.

$$
\text { Absorbance scavenging }=\left(1-\frac{A-B}{C}\right) \times 100
$$

where $A$ is the absorbance at $520 \mathrm{~nm}$ determined with test sample, $B$ is the absorbance at $520 \mathrm{~nm}$ determined with $\mathrm{HO}$ instead of $\mathrm{NaNO}_{2}$, and $C$ is the absorbance at $520 \mathrm{~nm}$ determined with $\mathrm{H}_{2} \mathrm{O}$ instead of the test sample, using a UV-Vis spectrophotometer.

\section{Measurement of Superoxide Dismutase-Like Activity (SODA)}

Superoxide dismutase (SOD)-like activity (SODA) was measured using according to Marklund and Marklund's 
method. The degree of oxidation of the pyrogallol catalyzing the reaction to convert hydrogen peroxide $\left(\mathrm{H}_{2} \mathrm{O}_{2}\right)$ is shown in SODA. ${ }^{24}$ For this, $0.2 \mathrm{~mL}$ of sample $(\mathrm{pH} 8.5)$ and Tris- $\mathrm{HCl}$ buffer (50 $\mathrm{mM}$ Tris [hydroxymethyl] aminomethane, $10 \mathrm{mM}$ EDTA, $\mathrm{pH}$ 8.5) $2.6 \mathrm{~mL}$ was added to $7.2 \mathrm{mM}$ pyrogallol $0.2 \mathrm{~mL}$ and mixed using a vortex mixer. After $10 \mathrm{~min}$, the reaction was stopped by adding $1.0 \mathrm{~N} \mathrm{HCl}$ solution. It was measured at $420 \mathrm{~nm}$ using a UV-Vis spectrophotometer. SODA demonstrated the difference in absorbance between the sample addition group and the non-addition group as a percentage.

$$
\text { Superoxide dismutase }- \text { like activity }=\left(1-\frac{B}{A}\right) \times 100
$$

where $A$ is the absorbance of standard solution without the added sample and $B$ is the absorbance of standard solution with the added sample .

\section{Measurement of Tyrosinase Inhibitory Activity}

Tyrosinase inhibitory activity was measured by a modified version of the method presented by Masamoto et al. ${ }^{25}$ To measure the mushroom tyrosinase-deactivating properties in in vitro conditions, $0.3 \mathrm{~mL}$ of $2.5 \mathrm{mM} 3.4$ dihydroxyphenylalanine (L-DOPA), $0.05 \mathrm{~mL}$ of the extract sample, and $0.1 \mathrm{M}$ phosphate buffer solution $(\mathrm{pH} 6.8$, total volume $1.5 \mathrm{~mL}$ ) were mixed using a vortex mixer, and then preincubated at $25^{\circ} \mathrm{C}$. Then, $0.05 \mathrm{~mL}$ of mushroom tyrosinase at 1380 units $\cdot \mathrm{mL}^{-1}$ (Sigma Co., USA) was added and then mixed using a vortex mixer. After that, the reaction was performed at $25^{\circ} \mathrm{C}$ for $2.0 \mathrm{~min}$.
Tyrosinase inhibitory activity $=\left(100-\frac{A-B}{A}\right) \times 100$

where $A$ is the absorbance value between 0.5 and $1 \mathrm{~min}$ of the reaction solution without sample, measured at $475 \mathrm{~nm}$ by a UV-Vis spectrophotometer; and $B$ is the absorbance value between 0.5 and $1.0 \mathrm{~min}$ of the reaction solution with sample, measured at $475 \mathrm{~nm}$ by a UV-Vis spectrophotometer.

\section{Preparation of Cream Material}

The cream formulas, based on distilled water, extracted oil, and additives, were prepared as listed in Table 1. Water, additives, and oil were weighed and then heated at $80^{\circ} \mathrm{C}$ in a water bath. Water was slowly added and vigorously mixed with oil in a mini mixer (DS-1800; Korea). Cream A was prepared without the extracted oil. Creams B, C, D, E, and F contained $1,5,10,20$, and $40 \mathrm{mg} \cdot \mathrm{mL}^{-1}$ of $\mathrm{SC}$ extract (SCE), respectively. Creams G, H, I, J, and K contained 1, 5, 10,20 , and $40 \mathrm{mg} \cdot \mathrm{mL}^{-1}$ of SCE fermentation (SCEF).

\section{Assessment of Safety}

The $\mathrm{pH}$ values were measured by a $\mathrm{pH}$ meter (professional meter pp-15; Germany) at $25^{\circ} \mathrm{C}$ for $10 \mathrm{~min}$. The glass electrode was immersed in a basic buffer solution or DI water before the $\mathrm{pH}$ measurement.

\section{Assessment of Stability}

To evaluate the stability according to environmental temperature, the stability of cream containing SCE or SCEF was evaluated at 4,25 , and $40^{\circ} \mathrm{C}$.

Table I Different Basic Cream Recipes Containing SCE and SCEF

\begin{tabular}{|l|c|c|c|c|c|}
\hline Sample & DI Water (g) & Extract Fermentation (g) & Avocado Oil (g) & Vitamin E (g) & Emulsifier (g) \\
\hline Cream A & 79 & 0.0 & 6.0 & 6.0 & 9.0 \\
Cream B & 76 & 3.0 & 6.0 & 6.0 & 9.0 \\
Cream C & 76 & 3.0 & 6.0 & 6.0 & 9.0 \\
Cream D & 76 & 3.0 & 6.0 & 6.0 & 9.0 \\
Cream E & 76 & 3.0 & 6.0 & 6.0 & 9.0 \\
Cream F & 76 & 3.0 & 6.0 & 6.0 & 9.0 \\
Cream G & 76 & 3.0 & 6.0 & 6.0 & 9.0 \\
Cream H & 76 & 3.0 & 6.0 & 6.0 & 9.0 \\
Cream I & 76 & 3.0 & 6.0 & 6.0 & 9.0 \\
Cream J & 76 & 3.0 & 6.0 & 6.0 & 9.0 \\
Cream K & 76 & 3.0 & & 9.0 \\
\hline
\end{tabular}

Note: $A$ is the cream without extracted oil $\left(0.0 \mathrm{mg} \mathrm{mL}^{-1}\right)$; $B$ is the SCE-based cream $\left(1.0 \mathrm{mg} \mathrm{mL}^{-1}\right)$; $C$ is the SCE-based cream $\left(5.0 \mathrm{mg}^{\mathrm{mL}} \mathrm{m}^{-1}\right)$; $\mathrm{D}$ is the SCE-based cream $\left(10 \mathrm{mg} \mathrm{mL}^{-1}\right)$; $E$ is the SCE-based cream $\left(20 \mathrm{mg} \mathrm{mL}^{-1}\right) ; \mathrm{F}$ is the SCE-based cream $\left(40 \mathrm{mg} \mathrm{mL}^{-1}\right)$; $\mathrm{G}$ is the SCEF-based cream $\left(1.0 \mathrm{mg} \mathrm{mL}^{-1}\right)$; $\mathrm{H}$ is the SCEF-based cream $\left(5.0 \mathrm{mg} \mathrm{mL} \mathrm{m}^{-1}\right)$; I is the SCEF-based cream $\left(10 \mathrm{mg} \mathrm{mL}^{-1}\right)$; $\mathrm{J}$ is the SCEF-based cream $\left(20 \mathrm{mg} \mathrm{mL}^{-1}\right)$; and $\mathrm{K}$ is the SCEF-based cream $\left(40 \mathrm{mg} \mathrm{mL}^{-1}\right)$. 
Table 2 ICP Analysis of the SCE

\begin{tabular}{|c|c|c|c|c|c|}
\hline Elen & 1.0 & 5.0 & 10 & 20 & 40 \\
\hline K & 23.71 & 149.66 & 315.48 & 660.42 & 1638.42 \\
\hline$M n$ & 0.15 & 0.80 & 1.62 & 2.80 & 5.69 \\
\hline $\mathrm{Fe}$ & 0.42 & 0.58 & 1.08 & 1.66 & 3.32 \\
\hline $\mathrm{Cu}$ & 0.02 & 0.02 & 0.04 & 0.07 & 0.12 \\
\hline $\mathrm{Zn}$ & 0.00 & 0.04 & 0.11 & 0.22 & 0.47 \\
\hline $\mathrm{Se}$ & 0.03 & 0.03 & 0.03 & 0.03 & 0.03 \\
\hline
\end{tabular}

\section{Results and Discussion}

\section{Microelement Analysis}

The results of inductively coupled plasma mass spectrometry (ICP) analysis of SCE are shown in Table 2, which indicates that $1.0 \mathrm{mg} \cdot \mathrm{mL}^{-1}$ of the SCE contains $23.71,0.42$, and $0.03 \mathrm{mg} \cdot \mathrm{kg}^{-1}$ of $\mathrm{K}, \mathrm{Fe}$, and $\mathrm{Se}$, respectively. When the amount of SCE increased, the content of these trace elements increased. In this regard, the increase in $\mathrm{K}$ was dominant, and the increases in $\mathrm{Mn}, \mathrm{Fe}, \mathrm{Cu}$, and $\mathrm{Zn}$ were not significant. The content of Se remained the same regardless of the concentration of SCE. These trace elements help the actions of many physiologically active substances both inside and outside the human body, and serve important roles, including antioxidizing and immunity activities.

\section{Measurement of Extract and Its Content of Flavonoids and Polyphenols}

The content of the SCE was $27.91 \mathrm{wt} \%$ in $100 \mathrm{~g}$ of SC. The extraction provided the same yield when the procedure was performed in water and ethanol. However, the yield of extract was lower than that in previous papers. ${ }^{26,27}$ This is due to the differences in the places where the SC was grown, as well as the conditions of culture and the method of extraction. ${ }^{26}$ The polyphenol content is shown in Table 3. The extract of ordinary SCE at $1.0 \mathrm{mg} \cdot \mathrm{mL}^{-1}$ provided $1.53 \pm 0.02 \mathrm{mg} \cdot \mathrm{g}^{-1}$ of polyphenol, while the same amount of EM SCEF provided a higher polyphenol content $\left(20.84 \pm 0.04 \mathrm{mg} \cdot \mathrm{g}^{-1}\right)$ than the non-fermented extract. The extraction results for EM SCEF at $5,10,20$, and $40 \mathrm{mg} \cdot \mathrm{mL}^{-1}$ were $25.82 \pm 0.04,29.13 \pm 0.05$, $42.07 \pm 0.05$, and $59.22 \pm 0.09 \mathrm{mg} \cdot \mathrm{g}^{-1}$, respectively.

In the case of the extract of ordinary SC, the corresponding results were $6.07 \pm 0.01,11.87 \pm 0.01,20.57 \pm 0.03$, and $40.95 \pm 0.02 \mathrm{mg} \cdot \mathrm{g}^{-1}$. So, the extract of EM SCEF had a higher content of polyphenol than found in the SCE group. As the concentration of the schisandra extract
Table 3 Content of Polyphenols in SCE and SCEF

\begin{tabular}{|l|c|c|}
\hline $\begin{array}{l}\text { Content of SCE or } \\
\text { SCEF }\left(\mathbf{m g ~ m L}^{-\mathbf{1}}\right)\end{array}$ & $\begin{array}{c}\text { Polyphenols in } \\
\text { SCE }\left(\mathbf{m g ~ g}^{-\mathbf{1}}\right)\end{array}$ & $\begin{array}{c}\text { Polyphenols in } \\
\text { SCEF }\left(\mathbf{m g ~ g}^{-\mathbf{1}}\right)\end{array}$ \\
\hline $\mathrm{I}$ & $1.53 \pm 0.02$ & $20.84 \pm 0.04$ \\
5 & $6.07 \pm 0.016$ & $25.82 \pm 0.04$ \\
10 & $11.87 \pm 0.01$ & $29.13 \pm 0.05$ \\
20 & $20.57 \pm 0.03$ & $42.07 \pm 0.05$ \\
40 & $40.95 \pm 0.02$ & $59.22 \pm 0.09$ \\
\hline
\end{tabular}

increased, the polyphenol content in the extract also increased. When compared, the extract of the EM SCEF group showed a higher content than the SC group. This implies that SCE reacted with the EM active solution and led to the multiplication of polyphenols, which are a very useful physiological reactive substance for the human body. According to many reports by other researchers, there is a proportional relationship between antioxidant ability and content of flavonoids. ${ }^{28-30}$ It was demonstrated that the flavonoid content depends on the concentrations of EM SCEF and SCE (Table 4). With low SCE and SCEF content, such as 1,5 , and $10 \mathrm{mg} \cdot \mathrm{mL}^{-1}$, no flavonoid value was found. When the concentration in the EM SCEF group and the SCE group was $40 \mathrm{mg} \cdot \mathrm{mL}^{-1}$, the flavonoid content was $2.79 \pm 0.02$ and $1.59 \pm 0.08 \mathrm{mg} \cdot \mathrm{g}^{-1}$, respectively. The results indicate that the EM SCEF has a high antioxidant ability.

\section{Measurement of Free-Radical Scavenging}

Free radicals in the body can promote biological aging, by reacting with lipids and proteins. To remove this phenomenon, many studies have investigated natural products. ${ }^{31}$ The DPPH radical scavenging test method is used in many natural products for antioxidant measurements using the electron-donating ability of antioxidants. ${ }^{32-34}$ The results of the antioxidant effects in the SCE and EM 
Table 4 Content of Flavonoids in SCE and SCEF

\begin{tabular}{|c|c|c|}
\hline $\begin{array}{l}\text { Content of SCE or } \\
\text { SCEF }\left(\mathrm{mg} \mathrm{mL}^{-1}\right)\end{array}$ & $\begin{array}{l}\text { Flavonoids with } \\
\text { SCE }\left(\mathrm{mg} \mathrm{g}^{-1}\right)\end{array}$ & $\begin{array}{l}\text { Flavonoids with } \\
\text { SCEF }\left(\mathrm{mg} \mathrm{g}^{-1}\right)\end{array}$ \\
\hline I & 0 & 0 \\
\hline 5 & 0 & 0 \\
\hline 10 & 0 & 0 \\
\hline 20 & 0 & $1.46 \pm 0.04$ \\
\hline 40 & $1.59 \pm 0.08$ & $2.79 \pm 0.02$ \\
\hline
\end{tabular}

SCEF groups are shown in Figure 1. In the case of the DPPH radical scavenging ability of SCE, as the concentration varied from $1.0,10$, to $40 \mathrm{mg} \cdot \mathrm{mL}^{-1}$, the antioxidant ability increased from $37 \%, 72 \%$, to $74 \%$. In the EM SCEF group, showed $63 \%, 67 \%$, and $79 \%$ antioxidant ability at the respective concentrations of $1.0,10$, and $40 \mathrm{mg} \cdot \mathrm{mL}^{-1}$. In the EM SCEF group, the minor change in antioxidant ability with concentration seems to be due to the reaction between EM SCEF and microbes to produce antioxidant substances. The antioxidant ability of SC was compared to some well-known antioxidants, such as BHT $(89 \%)$ and BHA (88\%). It was found that the freeradical scavenging ability of SC was not much different from them. In addition, SCEF has higher radical scavenging ability than SCE, even at low concentrations. This means that as SC and EM active solutions reacted with each other, the microbes produced physiologically active

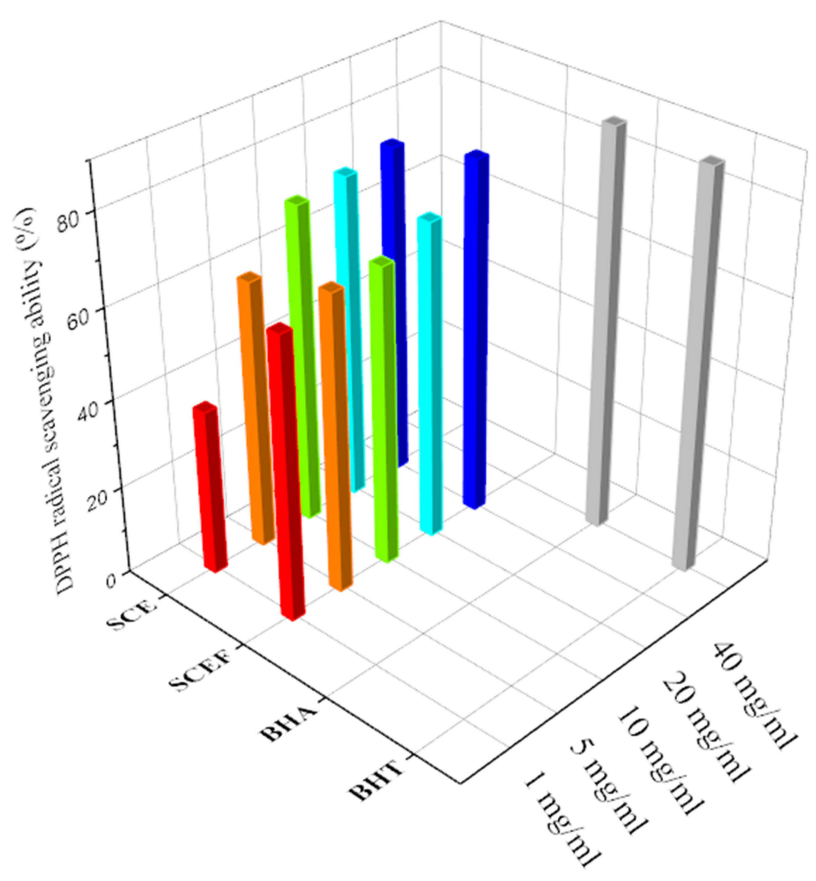

Figure I DPPH radical scavenging ability of the SCE and SCEF. materials which have antioxidant ability. Therefore, it is possible to produce material containing higher levels of antioxidants with lower amounts of EM SCEF than SCE. We concluded that this could solve a problem of dosage in manufacturing cosmetics, and simultaneously improve functional aspects of cosmetic products containing natural substances derived from plants.

\section{Measurement of Nitrite Scavenging Activity}

Nitrite reacts with secondary amine (a chemical compound in which two hydrogen atoms of ammonia are substituted with the hydrocarbon functional group R), producing nitrosamine, a notorious carcinogen; in other words, nitrite acts as a precursor for nitrosamine. Therefore, the formation of nitrosamine can be effectively inhibited by removing nitrite. ${ }^{35}$ If reactivity between the sample for analysis and nitrite is high, nitrite will be removed because it reacts in the ionized state, which leads to the inhibition of nitrosamine formation. This applies equally to other substances that exist in ion or electron forms, and the high reactivity of the sample is equivalent to or assessed as high activities of nitrite scavenging and antioxidation. The greater the amount of total phenol compounds in a sample, the more powerfully the reaction of nitrite scavenging occurs in the lower $\mathrm{pH}$ range, and, adversely, the scavenging effect decreases in upper $\mathrm{pH}$ range. ${ }^{36}$ Table 5 shows that the nitrite scavenging activity of SCE was $15 \%$ at $1 \mathrm{mg} \cdot \mathrm{mL}^{-1}, 40 \%$ at $10 \mathrm{mg} \cdot \mathrm{mL}^{-1}$, and $89 \%$ at $40 \mathrm{mg} \cdot \mathrm{mL}^{-1}$. On the other hand, SCEF showed nitrite scavenging activity of $51 \%$ at $1 \mathrm{mg} \cdot \mathrm{mL}^{-1}, 69 \%$ at $10 \mathrm{mg} \cdot \mathrm{mL}^{-1}$, and $98 \%$ at $40 \mathrm{mg} \cdot \mathrm{mL}^{-1}$. From this test, it was observed that as the concentration of both groups increased, the scavenging activity also increased. In addition, SCEF was superior to $\mathrm{SC}$ in its nitrite scavenging activity, which is similar to other experimental results. At a concentration of $1.0 \mathrm{mg} \cdot \mathrm{mL}^{-1}$, the difference in scavenging activity was $40 \mathrm{mg} \cdot \mathrm{mL}^{-1}$, the largest among the different concentrations, and the gap narrowed as the concentration increased. From this comparative experiment, through the EM fermentation process, the nitrite scavenging effect of SC, which was assessed as being quite good, improved further. This phenomenon can be attributed to the fermentation process generating more biologically active substances, which, in turn, led to an increase in the inhibition of nitrosamine formation, as well as many phenols, as crude plant ingredients, also contributing to the effective nitrite scavenging reaction. 
Table 5 Nitrite Scavenging Ability of SCE and SCEF at pH 2.5

\begin{tabular}{|l|c|c|}
\hline $\begin{array}{l}\text { Content of SCE } \\
\text { or SCEF } \\
\left(\mathbf{m g ~ m L}^{-1}\right)\end{array}$ & $\begin{array}{c}\text { Nitrite Scavenging } \\
\text { Activity with } \\
\text { SCE (\%) }\end{array}$ & $\begin{array}{c}\text { Nitrite Scavenging } \\
\text { Activity with } \\
\text { SCEF (\%) }\end{array}$ \\
\hline 1 & $15.53 \pm 0.32$ & $51.85 \pm 0.23$ \\
5 & $30.36 \pm 0.15$ & $64.68 \pm 0.15$ \\
10 & $40.00 \pm 0.15$ & $69.01 \pm 2.96$ \\
20 & $61.80 \pm 0.16$ & $84.33 \pm 0.23$ \\
40 & $89.39 \pm 0.08$ & $98.75 \pm 0.26$ \\
\hline
\end{tabular}

\section{SODA Measurement}

SOD is an enzymatic antioxidant which is able to detoxify and suppress the toxicity of $\mathrm{O}_{2}, \mathrm{H}_{2} \mathrm{O}_{2}$, peroxide, $\mathrm{OH}$ radicals, etc. ${ }^{37,38}$ SODA is shown in Table 6 for SCE (or SCEF) concentrations of $1.0,10$, and $40 \mathrm{mg} \cdot \mathrm{mL}^{-1}$. The SCE group had SODA of $6 \%, 18 \%$, and $41 \%$, while the EM SCEF group had SODA of $28 \%, 32 \%$, and $43 \%$ when the concentration increased from 1 to $40 \mathrm{mg} \cdot \mathrm{mL}^{-1}$. To analyze the difference in activity of the two groups, the difference in SODA value was higher at a low concentration of SCE and SCEF $\left(1.0 \mathrm{mg} \cdot \mathrm{mL}^{-1}\right)$ and smaller at a high concentration $\left(40 \mathrm{mg} \cdot \mathrm{mL}^{-1}\right)$. In this test, both groups had an outstanding level of SODA. ${ }^{26,39}$ Therefore, it can be judged that both SCE and SCEF have high, naturally originating, antioxidant ability.

\section{Measurement of Tyrosinase Inhibitory Activity}

The mechanism of tyrosinase inhibitory activity is very important in the cosmetic industry and can be used as a measure of the skin whitening effect. ${ }^{40}$ In the SCE group, tyrosinase inhibitory activity increased from $35 \%$ to $36 \%, 37 \%, 38 \%$, and $39 \%$ as the concentration of the extract increased (Table 7). In the EM SCEF group, tyrosinase inhibitory activity increased from $38 \%$ to $39 \%, 40 \%, 41 \%$, and $42 \%$ when the concentration increased. The EM SCEF had a more effective tyrosinase inhibitory activity than the

Table 6 SOD-Like Activity of SCE and SCEF

\begin{tabular}{|c|c|c|}
\hline $\begin{array}{l}\text { Content of SCE or SCEF } \\
\left(\mathrm{mg} \mathrm{mL}^{-1}\right)\end{array}$ & $\begin{array}{l}\text { SODA in } \\
\text { SCE (\%) }\end{array}$ & $\begin{array}{l}\text { SODA in } \\
\text { SCEF (\%) }\end{array}$ \\
\hline I & $6.66 \pm 4.64$ & $28.00 \pm 0.56$ \\
\hline 5 & $8.57 \pm 3.98$ & $30.14 \pm 0.58$ \\
\hline 10 & $18.62 \pm 3.08$ & $32.84 \pm 0.47$ \\
\hline 20 & $35.07 \pm \mid .21$ & $40.09 \pm 0.38$ \\
\hline 40 & $41.92 \pm 0.47$ & $43.25 \pm 0.17$ \\
\hline
\end{tabular}

Table 7 Inhibitory Effects of SCE and SCEF on In Vitro Melanin Synthesis by Tyrosinase

\begin{tabular}{|l|c|c|}
\hline $\begin{array}{l}\text { Content of SCE or } \\
\text { SCEF }\left(\mathbf{m g ~ m L}^{-1}\right)\end{array}$ & $\begin{array}{c}\text { Inhibitory } \\
\text { Effects with } \\
\text { SCE (\%) }\end{array}$ & $\begin{array}{c}\text { Inhibitory Effects } \\
\text { with SCEF (\%) }\end{array}$ \\
\hline 1.0 & $35.76 \pm 0.23$ & $38.88 \pm 0.48$ \\
5.0 & $36.29 \pm 0.32$ & $39.72 \pm 0.25$ \\
10 & $37.14 \pm 0.05$ & $40.35 \pm 0.36$ \\
20 & $38.46 \pm 0.01$ & $41.33 \pm 0.54$ \\
40 & $39.31 \pm 0.34$ & $42.54 \pm 0.05$ \\
\hline
\end{tabular}

normal extract, but there was not much difference. However, it is thought that both extracts have a skin whitening effect when they are used to make cosmetics. ${ }^{41}$

\section{Safety Evaluation}

The formulas of cosmetics with different concentrations of SCE and EM SCEF, ie, 0.0, 1.0, 5.0, 10, 20, and $40 \mathrm{mg} \cdot \mathrm{mL}^{-1}$, are shown in Figure 2. The manufactured cosmetics were formed in W/O dosage form by adding the aqueous phase to the oil phase. The $\mathrm{pH}$ value of the surface of human skin is generally between 4.5 and 6.5 , which is either slightly acidic or neutral. ${ }^{42}$ If the $\mathrm{pH}$ becomes alkaline, the skin's resistance will be weakened, leading to a propagation of germs and eventually to skin diseases. Therefore, it is highly recommended to use neutral or slightly acidic cosmetic products. The change in $\mathrm{pH}$ value with storage time is shown in Figure 3. Using the cream without $\mathrm{SCE}$, the $\mathrm{pH}$ was slightly increased to 6.23 after 60 days compared to its initial value of 6.25. The cream products with SCE concentrations of 1.0, 5.0, 10,20 , and $40 \mathrm{mg} \cdot \mathrm{mL}^{-1}$ had initial $\mathrm{pH}$ values of $5.53,3.87$, $3.43,3.15$, and 3.03 , respectively. These $\mathrm{pH}$ values did not change after 60 days. The EM SCEF-based creams with EM SCEF concentrations of $1.0,5.0,10,20$, and $40 \mathrm{mg} \cdot \mathrm{mL}^{-1}$ had initial $\mathrm{pH}$ values of $4.12,3.46,3.37,3.15$, and 2.98 , respectively. Similar $\mathrm{pH}$ values were observed after 60 days. These results mean that there was no significant difference in $\mathrm{pH}$ change in either group, and when the concentration of the extract increased, the $\mathrm{pH}$ value decreased. These results imply that there were no safety problems in using these cosmetic products.

\section{Effect of Temperature on Cosmetic Stability}

The evaluation of the effect of temperature on the stability of cosmetic products helps us to understand the chemical and physical changes of cosmetic products. It was found that several phenomena occurred, such as acidification, 


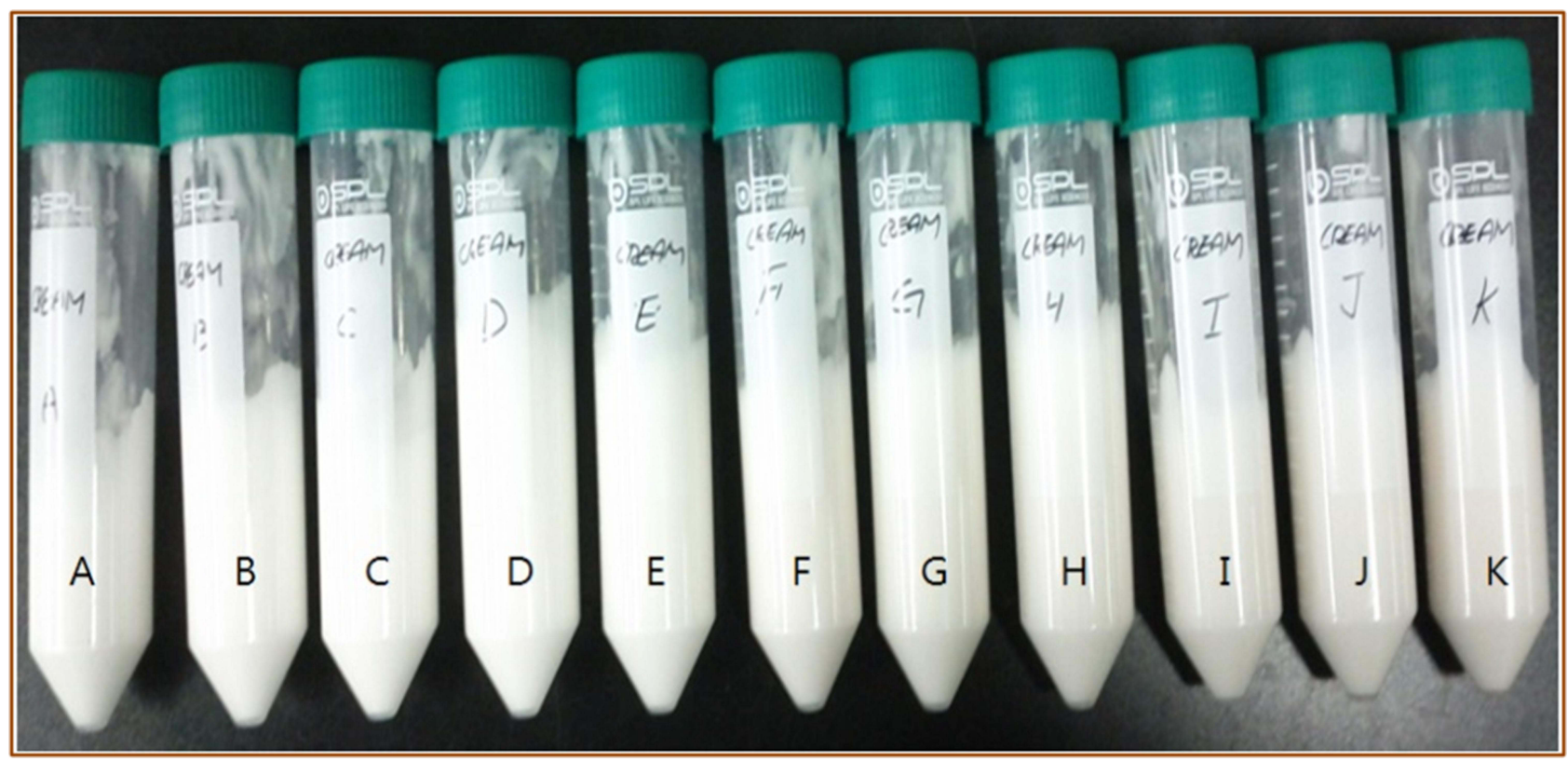

Figure 2 Photograph of the W/O emulsion containing SCE and SCEF.

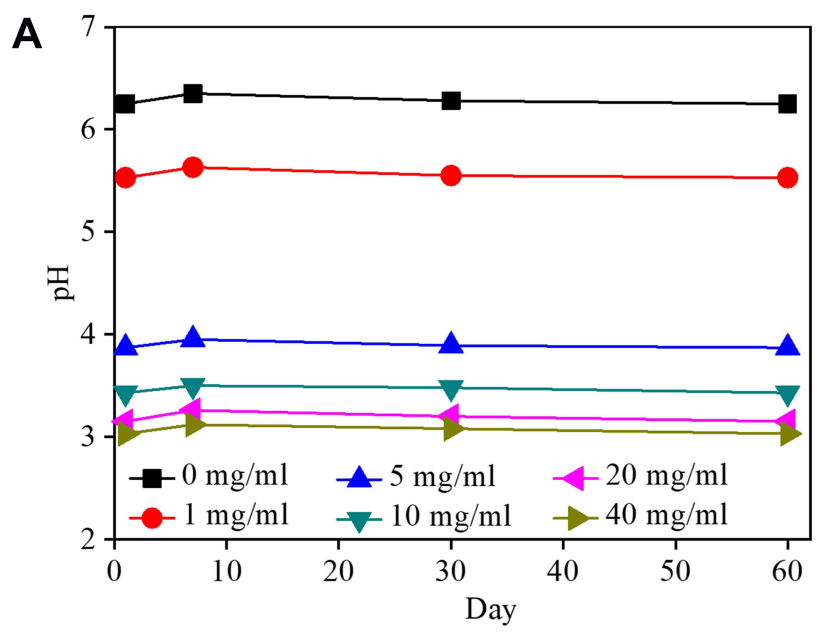

Figure 3 Change in $\mathrm{pH}$ values of the emulsion containing (A) SCE and (B) SCEF.

discoloration, evaporation, flotation, precipitation, turbidity, and separation at different temperatures in the cosmetic products after 60 days (Table 8 ).

\section{Conclusion}

In this study, we successfully synthesized both SCE and SCEF, which provide a source of biologically active substances with potential application in the design of innovative natural cosmetics with a broad spectrum of activity. In case of the antioxidant activity test of SCE, DPPH, radical

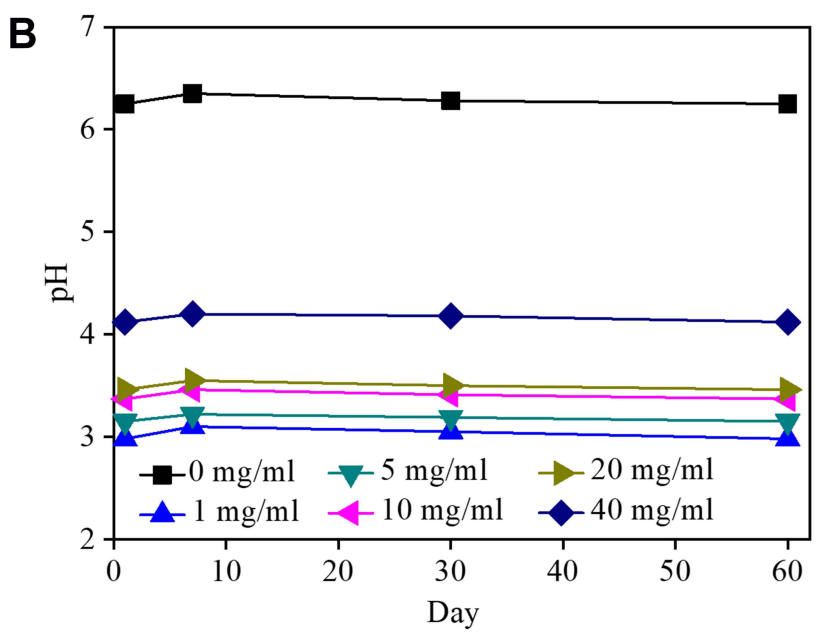

scavenging, nitrite scavenging, and SODA measurement of SC by EM fermentation were the highest among the tested groups. The SCE and SCEF showed little differences in their skin whitening effect. The measurement stability and the safety evaluation showed that the obtained substances contain effective chemical components that have antioxidant activity, suppressing skin aging and having a whitening effect in a weak acid range consistent with a $\mathrm{pH}$ of 6.25 2.98; therefore, these substances can be a nominated as a material for future cosmetic application. 
Table 8 Stability Test of the Emulsions Containing SCE and SCEF at Different Temperatures

\begin{tabular}{|c|c|c|c|c|c|c|c|c|c|c|c|}
\hline \multirow{2}{*}{$\begin{array}{l}\text { Temperature } \\
\text { Day }\end{array}$} & \multicolumn{11}{|c|}{$0^{\circ} \mathrm{C}$} \\
\hline & A & B & C & D & $\mathbf{E}$ & $\mathbf{F}$ & G & $\mathbf{H}$ & I & J & $\mathbf{K}$ \\
\hline I & 0 & 0 & 0 & 0 & O & 0 & 0 & O & 0 & 0 & O \\
\hline 2 & O & $\mathrm{O}$ & 0 & O & O & O & O & O & 0 & 0 & O \\
\hline 3 & O & O & 0 & O & O & O & O & 0 & O & 0 & O \\
\hline 4 & 0 & 0 & 0 & 0 & 0 & 0 & 0 & 0 & 0 & 0 & 0 \\
\hline 5 & 0 & 0 & 0 & O & 0 & 0 & 0 & 0 & 0 & 0 & 0 \\
\hline \multirow{2}{*}{$\begin{array}{l}\text { Temperature } \\
\text { Day }\end{array}$} & \multicolumn{11}{|c|}{$25^{\circ} \mathrm{C}$} \\
\hline & $\mathbf{A}$ & B & C & D & $E$ & $\mathbf{F}$ & G & $\mathbf{H}$ & I & J & $\mathbf{K}$ \\
\hline I & 0 & 0 & 0 & 0 & 0 & 0 & 0 & O & 0 & 0 & O \\
\hline 2 & 0 & 0 & 0 & 0 & 0 & 0 & 0 & O & 0 & 0 & O \\
\hline 3 & O & O & 0 & O & O & O & O & 0 & 0 & 0 & O \\
\hline 4 & O & O & 0 & 0 & O & 0 & O & 0 & 0 & 0 & O \\
\hline 5 & 0 & 0 & 0 & 0 & 0 & 0 & 0 & O & 0 & 0 & O \\
\hline \multirow{2}{*}{$\begin{array}{l}\text { Temperature } \\
\text { Day }\end{array}$} & \multicolumn{11}{|c|}{$40^{\circ} \mathrm{C}$} \\
\hline & A & B & C & D & $\mathbf{E}$ & $\mathbf{F}$ & G & $\mathbf{H}$ & I & J & $\mathbf{K}$ \\
\hline I & 0 & 0 & 0 & 0 & 0 & 0 & 0 & 0 & 0 & 0 & O \\
\hline 2 & 0 & 0 & 0 & 0 & 0 & 0 & O & O & 0 & 0 & O \\
\hline 3 & 0 & 0 & 0 & 0 & 0 & 0 & 0 & 0 & 0 & 0 & O \\
\hline 4 & O & O & 0 & O & O & O & O & 0 & O & 0 & O \\
\hline 5 & 0 & 0 & 0 & 0 & 0 & 0 & 0 & 0 & 0 & 0 & O \\
\hline
\end{tabular}

Note: O, stable; $X$, unstable.

\section{Acknowledgment}

This research was supported by Seokyeong University in 2020.

\section{Disclosure}

The authors report no conflicts of interest in this work.

\section{References}

1. Choi BR, Kim HK, Park JK. Effects of Schisandra chinensis fruit extract and gomisin A on the contractility of penile corpus cavernosum smooth muscle: a potential mechanism through the nitric oxide - cyclic guanosine monophosphate pathway. Nutr Res Pract. 2018;12 (4):291-297. doi:10.4162/nrp.2018.12.4.291

2. He J-L, Zhou Z-W, Yin J-J, He C-Q, Zhou S-F, Yu Y. Schisandra chinensis regulates drug metabolizing enzymes and drug transporters via activation of Nrf2-mediated signaling pathway. Drug Des Devel Ther. 2015;9:127-146.

3. Nowak A, Szyda MZ, Błasiak J, Nowak A, Zhang Z, Zhang B. Potential of Schisandra chinensis (Turcz.) Baill. in human health and nutrition: a review of current knowledge and therapeutic perspectives. Nutrients. 2019;11(2):333. doi:10.3390/nu1102 0333

4. Ramanathan L, Das NP. Studies on the control of lipid oxidation in ground fish by some polyphenolic natural products. J Agric Food Chem. 1992;40(1):17-21. doi:10.1021/jf00013a004
5. Yang S, Yuan C. Schisandra chinensis: a comprehensive review on its phytochemicals and biological activities. Arab J Chem. 2021;14 (9):103310. doi:10.1016/j.arabjc.2021.103310

6. Cho EG, Cho HI, Choi YJ. Antioxidant and antibacterial activities, and tyrosinase and elastase inhibitory effect of fermented Omija (Schizandra chinensis Baillon.) beverage. J Appl Biol Chem. 2010;53(4):212-221. doi:10.3839/jabc.2010.038

7. Park SJ, Seong DH, Park DS, et al. Chemical compositions of fermented Codonopsis lanceolata. J Korean Soc Food Sci Nutr. 2009;38(3):396-400. doi:10.3746/jkfn.2009.38.3.396

8. Dimidi E, Cox SR, Rossi M, Whelan K. Fermented foods: definitions and characteristics, impact on the Gut Microbiota and effects on gastrointestinal health and disease. Nutrients. 2019;11(8):1806. doi:10.3390/nu11081806

9. Moon S-H, Chang H-C. Rice bran fermentation using Lactiplantibacillus plantarum EM as a starter and the potential of the fermented rice bran as a functional food. Foods. 2021;10(5):978. doi: $10.3390 /$ foods 10050978

10. Katina K, Liukkonen KH, Kaukovirta A, Adlercreutz H, Heinonen SM, Lampi AM. Fermentation-induced changes in the nutritional value of germinated rye. $J$ Cereal Sci. 2007;46 (3):348-355. doi:10.1016/j.jcs.2007.07.006

11. Foolad N, Brezinski EA, Chase EP, Armstrong AW. Effect of nutrient supplementation on atopic dermatitis in children. Arch Dermatol. 2012;17:E1-E6.

12. Olle M, Williams IH. Effective microorganisms and their influence on vegetable production - a review. J Hortic Sci Biotechnol. 2031;88 (4):380-386. doi:10.1080/14620316.2013.11512979 
13. Uma MN, Abirami R. A review on: effective microorganisms and it applications. AJMR. 2019;8(4):121-129. doi:10.5958/2278-4853.20 19.00142 .3

14. Bzdyk RM, Olchowik J, Studnicki M, et al. The impact of Effective Microorganisms (EM) and organic and mineral fertilizers on the growth and mycorrhizal colonization of Fagus sylvatica and Quercus robur seedlings in a bare-root nursery experiment. Forests. 2018;9(10):597. doi: $10.3390 /$ f9100597

15. Chui CH, Cheng GYM. Growth inhibitory potential of effective microorganism fermentation extract (EM-X) on cancer cells. Int J Mol Med. 2004;14:925-929.

16. Chui CH, Hau DKP. Apoptotic potential of the concentrated effective microorganism fermentation extract on human cancer cells. Int J Mol Med. 2006;17:279-284.

17. Press MY. Conduct laboratory testing according to specifications and test methods of the food code. Food \& Administration; 2003:887-892.

18. Latimer GW. Official Methods of Analysis of AOAC International. 21 st ed. Hardcover; 2019

19. Kim J-H. Studies on the biological activity of Astragalus membranaceus extracts. Biomed Sci Lett. 2012;18(1):35-41.

20. Blois MS. Antioxidant determination by the use of a stable free radical. Nature. 1958;26(4617):1199-1200. doi:10.1038/1811199a0

21. Ahn YH, Yoo JS, Kim SH. An antioxidant capacity assay using a polyvinyl alcohol-based DPPH pellet. Bull Korean Chem Soc. 2010;31(9):2557-2560. doi:10.5012/bkcs.2010.31.9.2557

22. Kim BJ, Park YK, Kang BS. The effect of Rubifructus on the ovoluationandovaryinrats. Korean J Herb. 2001;16:139-152.

23. Gray JI, Dugan JRL. Inhibition of N-nitrosamine formation in model food system. J Food Sci. 1975;40(5):981-985. doi:10.1111/j.13652621.1975.tb02248.x

24. Marklund S, Marklund G. Involvement of superoxide a minoradical in the oxidation of pyrogallol and a convenient assay for superoxide dismutase. Eur J Biochem. 1975;47:468-474.

25. Masamoto YH, Ando Y, Murata Y, Shimoishi M, Tada K, Takahata K. Mushroom tyrosinase inhibitory activity of Esculetin isolated from seeds of Euphorbia lathyris L. Biosci Biotechnol Biochem. 2003;67(3):631-634. doi:10.1271/bbb.67.631

26. Kwon HJ, Park CS. Biological activities of extracts from Omija. Korean J Food Preserv. 2008;15:587-592.

27. Shin HO. Studies on physiological effect of purified polyphenol and the development of multiple emulsification. Gyeongbuk, Korea: Department of Cosmeceutical Science Graduate School, Daegu Haany University; 2009.

28. Markris DP, Rossiter JT. Comparison of quercetin and a non-orthohydroxy flavonol as antioxidants by competing in vitro oxidation reactions. J Agric Food Chem. 2001;49(7):3370-3377. doi:10.1021/jf0101071
29. An BJ, Park TS, Lee JY, et al. Anti-microbial effect of irradiated green tea polyphenol addition into cosmetic composition. J Korean Soc Appl Biol Chem. 2007;50:210-216.

30. Hong JY, Nam HS, Yoon KY, Shin SR. Antioxidant activities of extracts from fermented black jujube. Korean J Food Preserv. 2012;19(6):901-908. doi:10.11002/kjfp.2012.19.6.901

31. Youn JS, Shin SY, Wu Y, et al. Antioxidant and anti-wrinkling effects of Aruncus dioicus var. kamtschaticus extract. Korean J Food Preserv. 2012;19(3):393-399. doi:10.11002/kjfp.2012.19.3.393

32. Chan YY, Kim KH, Cheah SH. Inhibitory effects of Sargassum polycystum on tyrosinase activity and melanin formation in B16F10 murine melanoma cells. J Ethnopharmacol. 2011;137(3):1183-1188. doi:10.1016/j.jep.2011.07.050

33. Huang HC, Hsieh WT, Niu YL, Chang TM. Inhibition of melanogenesis and antioxidant properties of Magnolia grandiflora L. flower extract. BMC Complement Altern Med. 2012;6:12-72.

34. Jang MJM, Woo H, Kim YH, Jun DY, Rhee WJ. Effects of antioxidative, DPPH-radical scavenging activity and anti-thrombogenic by the extract of Sancho (Zanthoxylum schinifolium). Korean J Nutr 2005;38:386-394.

35. Fiddler W, Piotrowski EG, Pensabean JW, Doerr RC, Wassermann AE. Effect of sodium nitrite concentration on N-nitrosodimethylamine formation in frankfurters. $J$ Food Sci. 1972;37(5):668-673. doi:10.1111/j.1365-2621.1972.tb02721.x

36. Lee SJ, Chung MJ, Shin JH, Sung NJ. Effect of natural plant components on the nitrite-scavenging. J Food Hyg Safety. 2000;15 (2):88-94.

37. Kang BR, Changes of SOD-like activities and nitrite scavenging abilities by germination in brown rice Seoul National University of Technology Master's thesis (2003).

38. Yang YW, Hsu PYJ. The effect of Poly (D,L-Lactide-Co-Glycolide) microparticles with polyelectrolyte self-assembled multilayer surfaces on the cross-presentation of exogenous antigens. Biomaterials. 2008;29(16):2516. doi:10.1016/j.biomaterials.2008.02.015

39. Serrano MC, Pagani R, Manzano M, Comas JV, Portoles MT. Mitochondrial membrane potential and reactive oxygen species content of endothelial and smooth muscle cells cultured on poly-(epsilon-caprolactone) films. Biomaterials. 2006;27(27):4706. doi:10.1016/j.biomaterials.2006.05.007

40. Pawelek JM. After dopachrome. Pigm Cell Res. 1991;4(2):53-62. doi:10.1111/j.1600-0749.1991.tb00315.x

41. Invergar R, McEvily AJ. Studies on biological activity from extract of Crataegi Fructus. Korean J Herbol. 1992;17(1):29-38.

42. Wilkinson JB, Moore RJ. Harry's Cosmeticology. New York: Chemical Publishing Co., Inc; 1982:749.
Clinical, Cosmetic and Investigational Dermatology is an international, peer-reviewed, open access, online journal that focuses on the latest clinical and experimental research in all aspects of skin disease and cosmetic interventions. This journal is indexed on CAS.
The manuscript management system is completely online and includes a very quick and fair peer-review system, which is all easy to use. Visit http://www.dovepress.com/testimonials.php to read real quotes from published authors. 